\title{
The historical understanding of the Old Testament in South Africa: Colenso, Le Roux and beyond
}

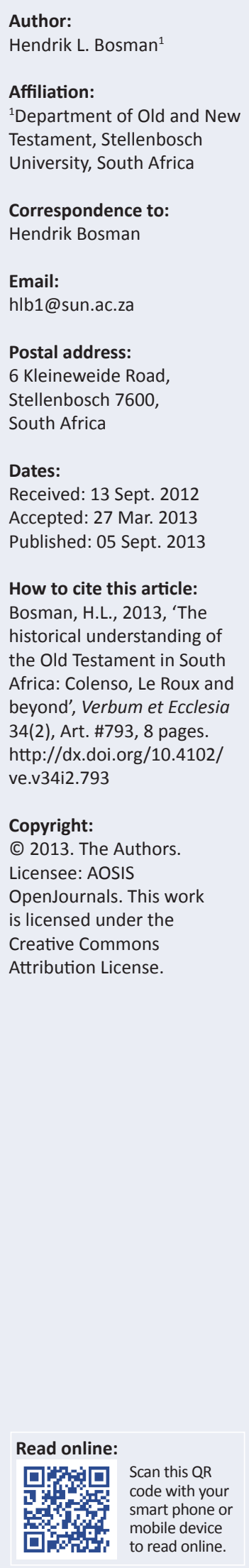

Isaiah Berlin quoted Archilochus to distinguish between two styles of academic reasoning that, to some extent, summarises the transition of historiography from Modernism to Postmodernism: 'The fox knows many things but the hedgehog knows one big thing.' The modernistic master narratives of the first half of the 20th century (quests for the 'centre of the Old Testament' etc.) were in obvious decline during the second half of the 20th century and, triggered by the Annales school of historiography social scientific methods, were incorporated into the study of ancient Israel. Historiography became less of an art that depended on an informed imagination and more like a science that presupposed empirical or social scientific research and a multidisciplinary approach to describe and explain the past. Against this backdrop, the historical understanding of the Old Testament in South Africa was discussed, starting with one of its oldest exponents, Bishop J.W. Colenso (disproving the chronological priority of the 'E source', rejecting the 'truth proving' function of archaeology and interpreting biblical texts within the historical context of its writing), and concluding with the current chair of the Old Testament Society of South Africa, Prof J.H. le Roux (influenced by Old Testament scholars such as G. von Rad and E. Otto and historiographers such as E. Troeltsch and R.G. Collingwood). The methodological principles of historiography suggested by Troeltsch (criticism, analogy and correlation) were adapted to describe and explain some trends in South African Old Testament historiography that go beyond a superficial division between maximalists and minimalists.

\section{Introduction}

This contribution does not focus on the Hebrew Bible or Old Testament as a literary artefact that was produced during the Iron Age by a literate elite, when the gradual evolving of this corpus of religious texts was influenced (amongst others) by its immediate Northwest Semitic cultural context, Assyrian treaties, Babylonian cosmology and Persian administration - and eventually by the Greek language and Hellenistic culture. The contribution reflects briefly on historical understanding in general and how it applies to a few examples of the understanding of the Old Testament in South Africa.

Some 20 years ago, I distinguished between different historiographers of Old Testament studies: some perform like intellectual cartographers who describe what they perceive to be the progress made in the discipline; others have a more hagiographic intent to describe those contributions which they consider to be worthy of inclusion in the canon of great dead Old Testament scholars (Bosman 1994:134-145). This particular contribution is a more humble but somewhat opportunistic attempt to, in cuckoo-like fashion, lay a few eggs in other scholar's nests.

Isaiah Berlin ([1954] 1986) quoted Archilochus ${ }^{1}$ to distinguish between two styles of academic reasoning that, to some extent, summarises the transition of historiography from Modernism to Postmodernism: 'The fox knows many things but the hedgehog knows one big thing'. ${ }^{2}$ The modernistic master narratives of the first half of the 20th century were concerned with progress and change, as well as revolution and transformation ${ }^{3}$ (similar to quests for the 'centre of the Old Testament'). These master narratives were in obvious decline during the second half of the 20th century and, triggered by the Annales school of historiography (Ferdnand Braudel, Lucien Febvre etc.), social scientific methods were incorporated into the study of ancient Israel. ${ }^{4}$ Historiography became less of an art that depended on an informed imagination and attempted to become a

1.Archilochus was an ancient Greek poet from the 7 th century BCE who was well known for his acerbic criticism of others; however, his writings only survive in fragmented quotations by other authors such as Aristotle.

2.Berlin ([1954] 1986) divided writers and thinkers into two categories: hedgehogs, who view the world though the lens of a single defining idea (e.g. Plato, Dante, Pascal, Hegel, Nietzsche, lbsen, Proust, etc.) and foxes, who draw on a wide variety of experiences (e.g. Herodotus, Aristotle, Erasmus, Shakespeare, Goethe, Balzac and Joyce).

3.Judt (2007:7) studied Europe since 1945 without attempting to formulate one single, all-embracing story or theme (hedgehog-like!), but did manage to identify several themes that shaped events during the past sixty to seventy years.

4.Kessler (2008) made a valuable contribution in this regard with the publication of his social history of ancient Israel. 
science that presupposed empirical or social scientific research and a multidisciplinary approach to describe and explain the past (Arnold 2007:833-837).

Against this backdrop, the historical understanding of the Old Testament in South Africa will be discussed, starting with one of its oldest exponents, Bishop John W. Colenso (disproving the chronological priority of the 'E source', rejecting the 'truth proving' function of archaeology and interpreting biblical texts within the historical context of its writing), and concluding with the current chair of the Old Testament Society of South Africa (OTSSA), Prof. Jurie H. le Roux (influenced by Old Testament scholars such as Gerhard von Rad and Eckart Otto and historiographers such as Ernst Troeltsch and Robin G. Collingwood). The methodological principles of historiography suggested by Troeltsch (criticism, analogy and correlation) will be adapted to describe and explain some trends in South African Old Testament historiography that go beyond a superficial division between maximalists and minimalists.

The reflection on the future of the historical understanding of the Old Testament will be linked to the role of the intellectual within society (not to speak of the so-called 'public theologian'!) according to which all intellectuals have the responsibility to unmask and challenge any manifestation of totalitarianism.

\section{Historical understanding and the Old Testament}

Although the research community has paid much attention to the historical development of the natural sciences (chemistry, mathematics, physics etc.), the development of historical understanding seems to be neglected (Lowenthal 1985 [2009]:xxvi). It took a whilst for the recognition of the inevitable social construction of knowledge to sink in. The presupposition that natural sciences deal with the 'raw experience' of natural phenomena, as opposed to the 'constructed interpretation' of historical phenomena still lingers in many a nook and cranny of the academic world - but hopefully not within the immediate audience of this contribution (Matthews 2007)!

Our experience and understanding of the past is shaped by our cultural legacies and the boundaries of language. We are confronted both with a present permeated by the past, manifested in a frequently bewildering array of traces available in artefacts and texts, art and music, architecture, agriculture et cetera, as well as with a past that is irretrievably gone - to realise that we are stuck with (re)presentations of the past and not with the past itself (Seixas 1996:765-767). Historical understanding has become the creative endeavour to balance the frustrating but challenging experience of an absent past with a pervasive past. Historical understanding, therefore, is as much an attempt to understand the past as it is concerned with the present. Charles W. Hedrick (2006:1) defines history as 'a story the present tells itself about the past and its meaning lies in the interaction of the two'.
According to John Burrow (2009:469-471), historiography at the beginning of the 20th century became critical of the 19th century 'liberal conception of history as the story of continuous growth of freedom ${ }^{5}$; whilst historians during the middle of the previous century were more attracted to the search for long term causes' and thus diverted their attention from the description of mere events and persons. ${ }^{6}$ Anthropology and sociology became favourite fountainheads for determining the long-term causes of historical events, as well as the underlying motivations for the way individuals acted. ${ }^{7}$ One could also mention the decline of Marxist ideology during the past thirty years as one of the reasons why historians shifted their focus from a reductionist understanding of history predominantly informed by politics and economics to a more holistic understanding in terms of culture. ${ }^{8}$ The late-20th century revival of cultural history is explained by Burrow (2009:504-505) as being the result of a coalescent awakening and an 'awareness of identity among groups which thought of themselves as hitherto suppressed, ignored or marginalized'. ${ }^{9}$

In a somewhat lighter vein, one can briefly turn to the way Egan (1989:280-292) depicted the different types of historical understanding:

- 'The Mythic' understanding usually enables the reinforcement of national and group identities.

- 'The Romantic' type of history has a predilection for the description of dramatic historical events and extraordinary individuals, emphasising emotional content and affective involvement.

- 'The Philosophic' approach seems to be prone to patternseeking investigations of the past and tends to generate sweeping statements and theories about the supposed underlying structure of history.

- 'The Ironic' attitude towards history is not driven by political subservience or upward social mobility but is interested in the details of history 'for their own sake' (at least mildly optimistic!)

We can now turn to the development of the historical understanding of the Old Testament: almost 225 years ago Johann Philipp Gabler delivered his Antrittsrede [inaugural lecture] at the now defunct university of Altdorf with the

5.Butterfield published The Whig interpretation of history in 1931, in which he took the assumption that progress formed the central theme of history to task. He pointed out that history could not be reduced to dividing historical agents into canonised ancestors who advanced progress and those who were perceived to be obstacles to progress - very few illustrations were given by him.

6.The French Annales school contrasted the longue duree of long-term structura changes with the more superficial attention given to events (histoire evenementielle).

7.Besides the members of the Annales school, such as Bloch, Braudel and Febvre, one must also recognise the significance of the cultural approach to historiography as exemplified by Huizinga, for whom the world had to be understood in terms of symbolic meanings and where resemblances were the result of symbolic connections (Burrow 2009:478-482)

8.Kelley (2005:1007) also describes how cultural history gave up the 'noble dream' of objectivity and recognised the fundamental role of imagination in the historical reconstruction.

9.Burrow (2009:505-506) compiles a comprehensive and somewhat familiar list of identities researched by historians in the latter part of the twentieth century: 'the identities researched by historians in the latter part of the twentieth century: "the history, ethnic history, peasant history, as well as the history of minority sexual inclinations, of bandits, of rebels and of unfashionable religious sects. Collectively, much of this has come to be known, not always accurately, as a "history from below"'. 
title: 'An address concerning the proper distinction between biblical and dogmatic theology and the proper determination of the goals of each. ${ }^{\prime 10}$ An important distinction was made by Gabler that is crucial for this paper: it is of great significance that the difference between biblical and dogmatic theology is being introduced by means of 'est ... e genere historico'. This phrase is usually translated to mean that biblical theology has a 'historical character' (genus historicum), but recently other translations have suggested that 'biblical theology is "historical in origin"'. The link between biblical theology and historical interpretation must also be understood in close connection to the conviction that 'timeless truths cannot be derived from time-conditioned ideas' (Stuckenbruck 1992:143). For Gabler, ironically, historical-critical exegesis became the procedure to identify the timeless truths in distinction to the 'time-conditioned elements of Scripture' that had to be 'removed from consideration as universal notions'.11

Historical interpretation in the 19th century is synonymous with Leopold von Ranke and his often misunderstood statement: 'wie es eigentlich gewesen ist'. Lester Grabbe (2007:25) sets the record straight by pointing out that Von Ranke belonged to the Romantic tradition that appreciated the importance of intuition in historical reconstruction. Von Ranke's emphasis on careful research based on documentation has been misrepresented as historical positivism. ${ }^{12}$ Julius Wellhausen, in 1878, made use of source criticism and it obviously resonates with elements of Von Ranke's approach. He made the crucial distinction between the time during which the text was written and the time the text was writing about.

In the 20th century two major trends developed in the historiography of the Old Testament on both sides of the Atlantic. In the USA, the Baltimore School (comprising William F. Albright [1932], John Bright [1959] and George E. Wright [1964]) considered the biblical record of Israel to be historically trustworthy and used 'Biblical Archaeology' to verify this presupposed historical trustworthiness. In Germany, the historical-critical approach generated in the 19th century was further developed by Albrecht Alt (1929) and Martin Noth (1956). They redefined the historicity of the biblical texts by taking 'the Wellhausen dictum that the narratives reflected the time when they were written' much further and by making use of archaeology in a much more critical manner than their trans-Atlantic counterparts (Grabbe 2007:30). Brief mention must also be made of Von Rad's Heilsgeschichte, in which he emphasised the development of different theological traditions in the Old Testament witnessing about the 'great deeds of God', rooted in an initial

10.Oratio de justo discrimine Theologiae biblicae et dogmaticae regundisque recte utriusque finibus. See the discussion of this seminal address in Stuckenbruck (1992).

11.Stuckenbruck (1992:149) makes a telling comment: 'Lessing's "ditch" was thus no [sic] so much addressed by Gabler as it was bypassed, despite his insistence that the search for a more adequate basis for theology began with the text's historical meaning.'

12.Evans (1997:16-18) summarised the important contribution by Von Ranke as follows, (1) establishing history as an academic discipline, (2) interpreting the past in its own terms and not superimposing criteria from the present and (3) developing source criticism as a critical method based on philological principles. historical credo, but not presupposing one theological centre for the whole of the Old Testament.

During the past two decades, the historical understanding of the Old Testament has been divided into two major schools of thought amidst vigorous personal attacks from both the so-called minimalists as well as the maximalists. The coining of these two terms, 'minimalist' and 'maximalist', have been claimed by both William Hallo (1980:3-5) and Axel Knauf (1991:171). The 'minimalist' is someone 'who accepts the biblical text only when it can be confirmed from other sources', whilst the 'maximalist' is a person 'who accepts the biblical text unless it can be proved wrong' (Grabbe 2007:23). ${ }^{13}$

\section{J.W. Colenso and historical understanding}

John William Colenso was born on 24 January 1814 in Cornwall into a lower-middle class Nonconformist family (Draper 2003a:108). Owing to unfortunate financial problems encountered by his father, he had to work extremely hard to earn enough money to enrol at St John's College, Cambridge in 1833 at the age of nineteen (Le Roux 1993:92-93). This ability to be resilient in times of adversity and to work hard stood Colenso in good stead later in his life. Colenso concentrated on mathematics at university, became a tutor at the famous, but then cash-strapped, public school, Harrow, and this lead to the writing of widely used school handbooks on algebra and arithmetic. Much of his eventual criticism of the Pentateuch was triggered by his mathematical predilection and not by his training in biblical criticism.

Several influences can be traced in Colenso's theological and hermeneutical frame of reference before he left for Natal. On the one hand, the poet and philosopher Samuel T. Coleridge provided him with a role model in whom romantic hermeneutics, idealistic philosophy and church political activism were impressively combined. ${ }^{14}$ On the other hand, the theologian Frederick D. Maurice advocated Christian universalism and the rejection of eternal damnation, intimately connected with his own brand of Christian socialism, stressing the presence of God in all persons (Draper 2003b:109; Whitelaw 1987:14). Both influences combine nonconforming theological reflection with ecclesial and political activism.

In 1853, Colenso was appointed and consecrated as the first Anglican missionary Bishop of Natal. Within the first year of his tenure as bishop, Colenso compiled a concise Zulu-English dictionary, as well as a Zulu grammar (fruits of his own diligent attempt to become fluent and not only

13.Grabbe (2007:23-24) argues persuasively that the distinction between 'maximalist' and 'minimalist' has become blurred: 'Almost all scholars are minimalists in certain parts of history - such as the "patriarchal" and settlement periods ... There are very few true minimalists ... those who accept the testimony of the Bible, unless it be falsified ... Some of those pursuing a minimalist interpretation sometimes give the impression that they alone are exercising methodological rigour ...

14.Draper (2003b:109) describes Coleridge as someone who 'late in his life, adopted Christianity and sought the renewal of the life of the Church of England centered on religious experience and ethics'. Le Roux (1993:104) is of the opinion that 'Coleridge taught Colenso to understand reality and the Bible in two ways; the 'Coleridge taught Colenso to understand reality and the Bible in two ways; the
empirical and the spiritual way ... It was Coleridge who gave him the courage to be empirical and the spiritual way ... It was
critical and to remain a missionary ...'. 
conversant in Zulu) and a Zulu translation of the Gospel of Matthew (Le Roux 1993:93).

According to David Whitelaw (1987:15-16), one can first trace Colenso's (1861) 'historical sense' in his commentary on the Book of Romans, in which he argues that:

no one can adequately understand Paul's message without a knowledge of the times in which he was writing, his personal circumstances, his hearer's background and the condition of the church of Rome at the time. (pp. i-ii)

A similar point of view is advocated by Jeff Guy (1983:73), who argues that Colenso's objective was 'to approach religious issues historically: to understand the concrete living situation in which the issue under consideration evolved before passing judgement, and not blindly invoking dead dogmas'.

On the title page of The Pentateuch and Book of Joshua critically examined, Colenso (1862) quotes Paul, 'We can do nothing against the Truth, but for the Truth' (2 Cor 13:8). In the controversial 'Essays and reviews' published in Quarterly Review, he writes:

Not to exceed, and not to fall short of facts - not to add, and not to take away, - to state the truth, the whole truth, and nothing but the truth - are the grand, the vital, maxims of Inductive Science, of English Law, and, let us add, of Christian Faith. (Colenso $1861: 309)^{15}$

This emphasis on 'truth' must be understood against the background Colenso's ongoing conversations with Zulu church members, students and translation assistants (Mokoena 2008; Mosothoane 1991). During the process of translating the Flood narrative in Genesis 6-9, a translation assistant, William Ngidi, asked:

Is all that true? Do you really believe that all this happened thus ... that all the beasts, and birds, and creeping things, upon the earth, large and small, from hot countries and cold, came thus by pairs, and entered the ark with Noah? And did Noah gather food for them all, for the beasts and birds of prey, as well as all the rest? (Colenso 1862:vii)

Colenso responded with integrity and sensitivity: 'My heart answered in the words of the Prophet, "Shall a man speak lies in the Name of the Lord?" ... I dared not to do so.' In his address to the Anthropological Society of London, Colenso (1865:ccix) referred to questions that cropped up in his Zulu congregation and which he had to answer truthfully and with integrity: 'questions with respect to the historical truth of the Scripture accounts of the Creation, the Fall, or the Deluge, or such a query as that which a grey-haired Zulu once put to myself, "Who was the father of Satan?"'.

The seven volumes on the Pentateuch and Joshua illustrate how Colenso developed as a biblical interpreter. Initially, in the first volume, he seemed to be preoccupied with the implausible dimensions of the ark, the logistics of the Exodus and the size of the tabernacle. One example will be given: at first he calculated that there must have been at least two million people taking part in the Exodus, if the biblical 15. I have not yet succeeded in accessing this particular volume of Quarterly Review. narrative is interpreted literally. Then Colenso goes to town by extrapolating from this calculation how logistically impossible a literal understanding of the narrative becomes: at least 200000 oxen as beasts of burden, 200000 lambs to commemorate Passover and to feed the Israelites each year. His coup de grace was:

Furthermore all kinds of dirt and filth had to be removed from the camp on a daily basis because the camp 'must be holy, so that he (Yahweh) will not see among you anything indecent and turn away from you' (Dt 23:14). It is unlikely that this could have been accomplished and it is therefore itself a very convincing proof of the unhistorical character of the whole narrative. (Colenso 1862:33-60)

In the following six volumes (published between 1862 and 1879) there are clear signs of growing academic insight and intellectual maturity. John Rogerson (1984:224-232) provides a useful survey of these six volumes. In Part 2, Colenso accepted the supplementary hypothesis to explain the authorship of the Pentateuch, in that he distinguished between an older Elohistic document written by Samuel and a younger Yahwistic work that was used for subsequent amplification and enlargement. Part 3 dealt with Deuteronomy and ample evidence was produced that the book was composed long after the time of Moses by pointing out the differences in the Hebrew vocabulary within the Pentateuch, as well as the similarity to the prophets (especially Jeremiah). Part 4 concentrated on Genesis 1-11, which he divided into two main sections according to his understanding of an Elohistic and Jehovist source. This division was based on a detailed study of verbal and stylistic characteristics - more sophisticated than some of the crude studies based on the mere use of different divine names. In Part 5, Colenso broadened his scope of attention and addressed issues in the Book of Genesis as a whole and although he did not formulate any significantly new hypotheses, he did succeed in refining existing material. Under the influence of Hermann Hupfeld, he identified a second, younger Elohist linked to Nathan the prophet. Part 6 was only completed in 1871 and incorporated a study of Exodus through to Joshua. His most important observation was that the legislative and cultic sections were probably written during and after the Babylonian Exile - a significant change in viewpoint because he, at first, presumed these sections to be part of the oldest section of the Pentateuch. ${ }^{16}$ It took another eight years before Part 7 was published. Colenso was now set on defending his opinion that the narrative sections of the Elohist were older than the legislative parts of the Pentateuch and succumbed to the suggestion made by the German critical orthodoxy renaming the Elohist as the Priestly document. He also looked further afield than the Pentateuch and commented, amongst others, on the supposed unhistorical nature of the version of Israelite history given in the Books of Chronicles. The impact of Colenso's Pentateuchal criticism on the church and civil society in Victorian England cannot be underestimated. In March 1865, Maurice wrote to Colenso:

To have a quantity of criticism about the dung in the Jewish camp ... thrown in my face, when I was satisfied that the Jewish history had been the mightiest witness to the people for a living 16.Influence by Karl Heinrich Graf (1866) and Abraham Kuenen (1870) can be discerned. 
God against the dead dogmas of priests, was more shocking to me than I can describe. (Maurice 1885:490) ${ }^{17}$

Was Colenso merely 'a mathematician dabbling with biblical figures and dimensions' or did his seven volumes on the Pentateuch and Joshua (about 3500 pages!) constitute 'the most remarkable achievement by a British scholar in the field of Old Testament criticism in the nineteenth century'? (Rogerson 1984:232-236).The significance of Colenso has been evaluated in different ways by historiographers of Old Testament studies. In England, Thomas K. Cheyne (1893:203) considered Colenso to be 'a genuine but not an eminent critic' and as someone who 'was not qualified to do thoroughly sound constructive work either in historical criticism or in theoretical theology'. ${ }^{18}$ His patronising conclusion is: 'Let us be thankful for all that he did in breaking the hard soil, and not quarrel with him for his limitations.'19 Almost seventy years later, John Emerton (1962) was still of the opinion that Colenso:

was no more than a brilliant amateur, and he has no disciples as far as his detailed reconstruction of the literary history of the Pentateuch is concerned. Yet it is clear that he was right in the main critical points he made, and that his opponents were wrong. (p. 267)

Peter Hinchcliff (1964), in the preface to his monograph on Colenso, considered him to be important in two ways: 'as one of the protagonists in the constitutional struggle that took place in South Africa' and 'as representative of "liberal" Anglican theology in the mid-nineteenth century'. In Germany, Ludwig Diestel ([1869] 1981:649) credited Colenso for stimulating debate in British scholarship but, in the end, denies that he achieved any advance in scholarship. The much later German survey of Old Testament scholarship by Hans-Joachim Kraus ([1956] 1982) makes no mention of Colenso at all.

In South Africa, Le Roux (1993) depicts Colenso as a tragic hero of a lost cause:

Colenso was a great Old Testament scholar. He mastered the Old Testament text in all its aspects and had a keen eye for detail. He succeeded in combining text analysis with creative imagination, scrutinized the final text so as to determine its imprecisions, found a way of linking faith and reason, illustrated that Pentateuch criticism does not undermine Scripture's authority ... Colenso was like a hero convinced of his views and who wanted to change the world for the better. But, in the end, he lost everything. (pp. 106-107)

Whilst Ferdinand Deist (1999) comes to the following conclusion:

C. thus took the problem of cultural relativism seriously without becoming a sceptic or subscribing to a dualistic view of Scripture, conclusions typical of many liberal theologians of the time.

17. One should remember the close personal ties Colenso had with Maurice who introduced him to his wife, Frances, and who officiated at their wedding.

18. Rogerson (1984:233) points out that Cheyne was somewhat impatient with 'anyone who does not reach his [Cheyne's] position in one leap'.

19.The negative response in England elicited by Colenso's biblical criticism can fill several pages and one example will have to suffice: Matthew Arnold (1960:94) referred to Colenso, the 'Lord Bishop of Natal' as 'that favourite pontiff of the Philistines'. I will not dwell on references to Colenso as the 'wicked Bishop' or even 'the Evil one' (Cox 1888:30). Larsen (1997:433-458) described Colenso's biblical 'the Evil one' (Cox 1888:30). Larsen (1997:433-458)
criticism against the background Victorian England.
One might perhaps anachronistically term his reading strategy 'proto-form historical', his hermeneutics 'existential', and his view of Scripture 'dialectical'. (p. 204)

\section{J.H. le Roux and historical understanding}

Jurie Hendrik le Roux's historical understanding has been informed by his wide-ranging academic studies: after completing his basic theological training at the University of Pretoria (1963-1970), he completed a MA in Sociology (1972) that investigated Max Weber's suggestion that Protestantism was responsible for the emergence of capitalism. In the following ten years, he completed two doctorates: the first was in early Church History (1976) on Gaudentius of Brixia's view of the Passover and the second in Old Testament (1981 on the Exodus and Sinai traditions, in which his appreciation for Gerhard von Rad was obvious. In 1994, Le Roux added an Honours degree in Philosophy to his already crowded academic trophy cabinet (Human 2006:801-819).

Thus Le Roux painstakingly constructed a historical consciousness that was influenced by the textual discipline of Church History, the sociological awareness of ideology, as well as the dynamics between text and social context, the historically informed and aesthetically pleasing theological reflection of Von Rad and a self-critical attitude stimulated by philosophical hermeneutics. Combine this academic training with a longstanding appreciation for art, literature and music and you have the makings of an exceptional historian! ${ }^{20}$

The following brief discussion of elements of Le Roux's substantial research output does not do justice to the whole, but is also not intended as a hagiographic resume. Le Roux's discussion of thirty years of South African Old Testament scholarship published in 1993 in a certain way resembles American politics - a 'two horse race' of text immanent (synchronic) and historical (diachronic) approaches to the interpretation of the biblical texts. Despite some criticism resulting from the omission or neglect of certain scholars, this remains a remarkable achievement of erudition and sympathetic engagement with the guild of Old Testament scholarship as a whole.

One year after his survey of South African Old Testament scholarship, Le Roux (1994:198-199) is not yet convinced that the historical-critical method has fully arrived in South Africa. He argues that the main reason for this 'late arrival' is: 'South Africa has missed the Aufklärung. ${ }^{21}$ In the end, Le Roux is less worried about the future of historical criticism as an exegetical methodology and more concerned about the cultivation of a historical understanding of text and context (Lombaard 2006:912-925).

When Le Roux (1997:401-423) engages with our 'historical heritage', he deals with the historical approach to the

20.It is somewhat unfortunate that Le Roux never discovered the enjoyment of good wine!

21.Le Roux uses John W. Colenso and Johannes Du Plessis as examples of critical voices that were smothered by local intellectual intolerance. 
Old Testament by starting with the inaugural lecture of Gabler (discussed earlier in this contribution). Against the background of this lecture, Le Roux (1997:403-404) identified several 'typical features' of historical thinking: history can contribute to come to grips with aspects of the Bible's unintelligibility, it has been used to identify so-called Biblical truths and to determine elements of the original context. It is significant that Le Roux (1997:406) specifically placed emphasis on the principles for historical interpretation according to Troeltsch (1913), (1) to explain every aspect of life in view of its causal relations, (2) methodological doubt that does not allow final and conclusive results and (3) understanding the past in terms of analogy. Looking at the 20th century, Le Roux (1997:410) points out several 'strange dichotomies' (perhaps even binary equations) that influence historical understanding in Old Testament scholarship: knowing and believing, what the Bible meant then and what it means now, descriptive and normative, retaining the dualism in such a way that the resulting tension becomes a creative space in which historical understanding can thrive and the interdependence of theology and history. For Le Roux, (1997:401) 'historical study must be a free, open and creative enterprise'.

In an article on New Testament scholarship, Le Roux (2007:983) attempted to rethink the foundations of historical understanding as a prerequisite for renewal in the study of the Bible, defining 'history' not as a discipline concerned with 'facts about and exact depictions of the past', but poignantly as 'a form of homecoming' that 'does not lie in a method ... but in ourselves'. Le Roux (2007:984) positions biblical scholarship in South Africa at the 'intersection between the particular (Africa / South Africa) and the universal (western scholarship)' and argues that the tension between the two contexts must never be resolved. One could ask whether the juxtaposition of Africa as the 'particular' and Western scholarship as 'the universal' is an unfair privileging of the latter? To my mind, one should be more careful in using the concept 'universal', especially with contingent matters such as 'historical understanding'. 'Western scholarship' is, in many ways, a generalising intellectual fiction that glosses over the historically conditioned particularities of the constituent parts.

Vintage Le Roux (1997:987) is his depiction of synchronic studies as being 'a very optimistic undertaking' because it presupposes that meaning 'lurks just below the surface and awaits the moment of retrieval through the right method'. His description of diachronic studies seems to have an autobiographical ring to it:

When toiling diachronically a feeling of loss is rather experienced. It is like being plunged into mourning because the eye can never penetrate ... the reason for this is because signs in the text are only traces of what once was or happened; traces which are present but also absent, illuminating but also obscuring. (Le Roux 1997:987)

Historically minded biblical scholarship requires an intellectual framework to flourish and the most important characteristics of this intellectual space are: high-level philosophical thought, critical acumen, sharp historical insight and a religious feeling (Le Roux 2007:988). Besides the public space for scholarly engagement, Le Roux (1997:990) reminds the guild of the equal importance of individuality of historical understanding: 'Knowledge of the past is gained when the past is re-enacted in the mind of the historian. All history is therefore "the re-enactment of past thought in the historian's own mind"' (echoes of Collingwood!). The interaction between the public and private space of scholarly reflection is not clearly addressed.

Finally, I would like to conclude with Le Roux's (2009) insightful discussion of his own academic locus, the Department of Old Testament Studies at the University of Pretoria. After situating the department in the international world of scholarship, Le Roux (2009) relates Old Testament scholarship with 'Africa's pain':

Africa is a harsh continent. Sweltering heat, floods, late afternoon thunderstorms, droughts and all kinds of destructive pests have plagued Africa for centuries. Every day, poverty, AIDS, corruption and bad governance devastate the lives of ordinary people. And those who still have the courage to hope, think only of trivial things like shelter for the night, a blanket, a loaf of bread, a part-time job and clean water. (Le Roux 2009:1-2)

This depiction hovers somewhere between Afro-pessimism and Afro-realism. ${ }^{22}$ Perhaps this liminal position, between pessimism and realism, is exactly where Old Testament interpretation must take place!? Le Roux goes further and denies that the Old Testament can provide all these basic human needs. To his credit, he then challenges Old Testament scholarship to reverse the usual order of first the explanation of the text and then the application of the text. Interpretation of the biblical text in South Africa 'calls for application and the exegete's life context determines the exegesis of a text'.

Although Le Roux (1993) refrained from any discussion of his own work in A story of two ways, he does provide a brief but informative autobiographical description of his own position within his academic department (Le Roux 2009:3). He acknowledges how his initial study of Church History and his toil with patristic texts contributed to his realisation of how important historical interpretation is 'for life and theology'. His romantic hermeneutics becomes apparent when he argues that historical investigation can only be achieved through the re-enactment 'or reliving of Israel's past' - an endeavour only achievable when it recognizes the humbleness of our existence and our shared humanity. After thirty years, the voice of Von Rad can still be heard when Le Roux describes the manner in which Israel 'actualised God's historical deeds in the light of their present situation, they contextualised their history from the perspective of faith, and continuously re-told, relived and re-enacted their past'. Robin Collingwood and Hans-Georg Gadamer are still partners in conversation when Le Roux argues that the actualisation of the Old Testament for the present day depends on the exegete's competence to immerse him-/ herself in the text and relive Israel's past' (Le Roux 2009:3).

22 .It is almost as if Le Roux will struggle to 'come home' in such an environment. 


\section{Conclusion: The future of historical understanding in South African Old Testament studies ${ }^{23}$}

To take a leaf out of Febvre's early Annales approach: what historical mentalities or assumptions must we nurture in future through our tuition and in our research?

To my mind, we must be aware of, but steer clear of, introspective White middle-class guilt (the knee-jerk petit bourgeoisie reaction that is more focused on self preservation than in making changes for the greater good of all concerned). We must refrain from odious political subservience that is often rooted in middle-class guilt and that sometimes leads to succumbing to the Lorelei attraction of upward mobility in university and governmental administration. How can we get rid of a repugnant emotional 'onanism' that is nurtured by religiously induced low self-esteem that cries out for some sort of salvation - predominantly personal and very seldom collectively? ${ }^{24}$ Echoing Le Roux: if historical understanding is a 'free, open and creative enterprise', then historical interpretation can lead to theological-ethical reflection about the Old Testament that exemplifies the same characteristics (Lombaard 2006:912-925).

How can the historical study of ancient Israel steer clear of a 'whiggish' type of monocausal reconstruction that boils down to a reductionist but popular rendition of the past - one example: a kind of 'Proletarian Progress' according to which the supposed peasant revolution in ancient Israel forms the climax of social historical development?25

Today, many South Africans suffer from historical amnesia: some feel angry when they are reminded of their (not 'the'!) past, others experience guilt (sometimes even fear) when they reflect on their past. This historical amnesia makes us underprepared to face the future and, perhaps, the historical understanding of the Hebrew Bible and Old Testament can contribute towards establishing a more general historical awareness that makes a humble but very necessary contribution in this regard. In the game of historical understanding, hedgehogs and foxes have parts of equal importance to play: specialists who know everything of something must be in conversation with the generalists who know something of everything. ${ }^{26}$ Although this plea will probably fall on deaf ears in the National Research Foundation's process to rate academic scholars, members of the OTSSA will have to revisit the scholarly dynamics within the guild of its members.

In Colenso and Le Roux, we have exemplary 'foxy' historians who challenge us as a guild of scholars (foxes and hedgehogs

23.Perhaps this subheading should read: 'Back to the future'!?

24.Some of these criticisms were derived from the insightful analysis made by Burrow (2009:490-491).

25.With apologies to the author of Pilgrim's Progress, John Bunyan.

26.Bill Bryson's (2004) A short history of nearly everything, is probably one of the best recent examples of what a 'foxy' historian is capable of - the widespread popular and critical acclaim is also an indication of the need for this approach in an era of rampant specialisation. alike!), who continuously negotiate identity and struggle to create meaning betwixt a bewilderingly complex past and an uncertain but potentially exciting future. If we are what we remember, we must establish more dialogue amongst the diverging (contesting!) renditions of the past (both biblical and South African) to have any chance of maintaining critical scholarly intersubjectivity in the future. This scholarly dialogue can be advanced by being reminded of Troeltsch's criteria for historical understanding through the lens of subsequent theological and philosophical reflection: maintaining a rigorous critical appraisal of biblical texts and contexts then and now, appropriating plausible examples of analogy mediated through but not inhibited by own personal experience and rethinking the principle of correlation that is rooted not only in historical cause-and-effect but also in agency.

The Old Testament scholarship in South Africa (OTSSA etc.) is challenged to maintain a critical, creative and inclusive scholarly space that nurture different and contesting agencies of historical understanding - with diverging ranges of metaphysical (atheist, agnostic and theistic) assumptions, but committed to maintain the dialogue required by the ongoing deferment of historically conditioned meaning!

\section{Acknowledgements}

The deficiency of language is acutely felt when one tries to express gratitude. This article is a deficient attempt to express profound gratitude towards Jurie le Roux: an empathetic historian, an imaginative theologian and a stimulating friend over many decades.

\section{Competing interests}

The author declares that he has no financial or personal relationships that may have inappropriately influenced him in writing this article.

\section{References}

Albright, W.F., 1932, The archaeology of Palestine and the Bible, Revell, New York.

Alt, A., 1929, Der Got der Väter: Ein Beitrag zur Vorgeschichte der israelitischen Religion. Beiträge zur Wissenschaft vom Alten und Neuen Testament 48, Kohlhammer, Stuttgart.

Arnold, B.T., 2007, 'History and historiography, OT', in K.D. Sakenfeld (ed.), The new intepreter's dictionary of the Bible, $D-H$, vol. 2, pp. 833-837, Abingdon, Nashville.

Arnold, M., 1960, 'Preface to the first edition of essays in criticism', in F. Neiman (ed.), Essays, letters and reviews by Matthew Arnold, Cambridge University Press, Cambridge.

Berlin, I., [1954] 1986, The hedgehog and the fox: An essay on Tolstoy's view of history, Simon \& Schuster, New York.

Bosman, H.L., 1994, 'Cartographers, canons and cuckoos: The historiography of Old Testament studies', Skrif en Kerk 14, 134-145.

Bright, J., 1959, A history of Israel, SCM, London.

Bryson, B., 2004, A short history of nearly everything, Black Swan, London.

Burrow, J., 2009, A history of histories. Epics, chronicles, romances and inquiries from Herodotus and Thucydides to the twentieth century, Penguin, London.

Butterfield, H., 1931, The Whig interpretation of history, Bell, London.

Cheyne, T.K., 1893, Founders of Old Testament Criticism, Methuen, London.

Colenso, J.W., 1861, St Paul's epistle to the Romans: Newly translated and explained from a missionary point of view, Mission Press, Ekukanyeni.

Colenso, J.W., 1862-1872, The Pentateuch and Book of Joshua critically examined, Parts I-VI, Longmans \& Green, London. 
Colenso, J.W., 1865, 'On the efforts of missionaries amongst savages', Journal of the Anthropological Society of London 3, ccxlviii-cclxxxix. http://dx.doi. of the Anthropological
org/10.2307/3025325

Cox, G.W., 1888, The life of Bishop Colenso, DD, Bishop of Natal, vol. I-II, Ridgway, London.

Deist, F.E., 1999, 'Colenso, John William (1814-83)', in J.H. Hayes (ed.), Dictionary of biblical, A-J, pp. 203-204, Abingdon, Nashville.

Diestel, L., [1869] 1981, Geschichte des Alten Testamentes in der christlichen Kirche, Mauke's Verlag, Jena.

Draper, J.A., 2003a, 'Bishop John William Colenso and History as unfolding natrrative', Journal of Theology in Southern Africa 117, 97-105.

Draper, J.A., 2003b, 'Colenso's commentary on Romans: An exegetical assessment', in J.A. Draper (ed.), The eye of the storm: Bishop John William Colenso and the crisis of biblical interpretation, pp. 104-125, Cluster, Pietermartizburg.

Egan, K., 1989, 'Layers of historical understanding', Theory and Research in Socia Education 17(4), 280-294. http://dx.doi.org/10.1080/00933104.1989.10505594

Emerton, J.A., 1962, Old Testament scholarship and the church - A century after Colenso. A sermon delivered before the University of Cambridge on Sunday 11 March 1962, Blackwell, Oxford.

Evans, R.J., 1997, In defence of history, Granta, London.

Grabbe, L.L., 2007, Ancient Israel. What do we know and how do we know it?, T\&T Clark, London.

Graf, K.H., 1866, Die geschichtlichen Bücher des Alten Testaments. Zwei historischkritischen Untersuchungen, Weigl, Leipzig.

Guy, J., 1983, The heretic. A study of the life of John William Colenso 1814-1883, Ravan, Johannesburg.

Hallo, W.W., 1980, 'Biblical history in its Near Eastern setting: The contextual approach' in C.D. Evans et al. (eds.), Scripture in context: Essays in the comparative method. Pittsburg theological monograph series 34, pp. 1-26, Pickwick, Pittsburgh.

Hedrick, C.W., Jnr., 2006, Ancient history: Monuments and documents, Blackwell, Oxford. http://dx.doi.org/10.1002/9780470773741

Hinchcliff, P.B., 1964, John William Colenso, Nelson, London.

Human, D., 2006, 'Jurie Hendrik Le Roux - Deernisvolle Mens en Veelsydige Akademikus', Old Testament Essays 19(3), 801-819.

Judt, T., 2007, Postwar. A history of Europe since 1945, Pimlico, London.

Kelley, D.R., 2005, 'History, idea of', in M.C. Horowitz (ed.), New dictionary of the history of ideas, vol. 3, pp. 1005-1008, Scribners, Detroit.

Kessler, R., 2008, The social history of ancient Israel: An introduction, Fortress, Minneapolis.

Knauf, E.A., 1991, 'King Solomon's copper supply', in E. Lipinsky (ed.), Phoenicia and the Bible. Studia Phoenicia 11, pp. 167-186, Peeters, Leuven.

Kraus, H.-J., [1956] 1982, Geschichte der historisch-kritischen Erforschung des Alten Testaments, Neukirchener Verlag, Neukirchen-Vluyn.

Kuenen, A., 1870, De Godsdienst van Israel tot den Ondergang van den joodschen Staat, Kruseman, Haarlem.

Larsen, T., 1997, 'Bishop Colenso and his critics: The strange emergence of biblical criticism in Victorian Britain', Scottish Journal of Theology 50, 433-458. http:// dx.doi.org/10.1017/S0036930600049759
Le Roux, J.H., 1972, "n Godsdienssosiologiese ontleding van Max Weber se stelling dat Protestantisme verantwoordelik is vir kapitalisme', Unpublished MA thesis in Sociology, Department of Sociology, University of Pretoria.

Le Roux, J.H., 1976, 'Die paasbeskouing van Gaudentius van Brixia', Unpublished DD dissertation in Church History, Department of Church History, University of South Africa.

Le Roux, J.H., 1981, 'Eksodus en Sinai', Unpublished DTh dissertation in Old Testament, Department of Old Testament Studies, University of South Africa.

Le Roux, J.H., 1994, 'Historical criticism - The end of the road?', Old Testament Essays 7(4),198-202.

Le Roux, J.H., 1993, A story of two ways. Thirty years of Old Testament scholarship in South Africa, Verba Vitae, Pretoria.

Le Roux, J.H., 1997, 'Our historical heritage', Old Testament Essays 10(3), 401-423.

Le Roux, J.H., 2007, 'Historical understanding and rethinking the foundations', Hervormde Teologiese Studies 63(3), 983-998.

Le Roux, J.H., 2009, 'Old Testament Studies: The story of a department', Verbum et Ecclesia 30(3), Art.\#182, 9 pages.

Lombaard, C., 2006, 'Teks en Mens. JH LeRoux se Lees van die Bybel binne die Konteks van Hoofstroom-Eksegese in Suid-Afrika', Old Testament Essays 19(3), 912-925.

Lowenthal, D., [1985] 2009, The past is a foreign country, Cambridge University Press, Cambridge.

Matthews, V.H., 2007, Studying the ancient Israelites. A guide to sources and methods, Baker Academic, Grand Rapids.

Maurice, F.D., 1885, The life of Frederick Denison Maurice, chiefly told in his own letters, 4 th edn., MacMillan, London.

Mokoena, H., 2008, "'The Queen's bishop". A convert's Memoir of John W. Colenso', Journal of Religion in Africa 38, 312-342. http://dx.doi. org/10.1163/157006608X323513

Mosothoane, E., 1991, 'John William Colenso: Pioneer in the quest for an authentic African Christianity', Scottish Journal of Theology 44(2), 215-236. http://dx.doi. org/10.1017/S0036930600039120

Noth, M., 1956, Geschichte Israels, 3rd edn., Evangelisch Verlagsanstalt, Berlin.

Rogerson, J., 1984, Old Testament criticism in the nineteenth century. England and Germany, SPCK, London.

Seixas, P., 1996, 'Conceptualizing the crowth of historical understanding', in D.R. Olsen $\&$ N. Torrance (eds.), The handbook of education and human development, pp. 765-783, Blackwell, Oxford.

Stuckenbruck, L.T., 1992, 'Johann Philipp Gabler and the delineation of biblical theology', Scottish Journal of Theology 52(2), 139-157. http://dx.doi.org/10.1017/ S003693060005359X

Troeltsch, E., 1913, 'Historiography', in J. Hastings (ed.), Religion and ethics, pp. 719720, T\&T Clark, Edinburgh.

Wellhausen, J., 1878, Prolegomena zur Geschichte Israels, Reimer, Berlin.

Whitelaw, D., 1987, 'A crisis of credibility. Contemporary dialogue with Colenso and Du Plessis', Journal of Theology for Southern Africa 60, 12-27.

Wright, G.E., 1964, Archaeology, history and theology, SCM, London. 